\title{
AMSTERDAM, NEDERLANDS SCHEEPVAARTMUSEUM (NETHERLANDS MARITIME MUSEUM)
}

\section{Address: Kattenburgerplein 1}

The museum had its origin in a grand exhibition of Dutch shipping, the Eerste Nederlandsche Tentoonstelling op Scheepvaartgebied, held in Amsterdam in 1913. Not long after, in 1916, on the instigation of Queen Wilhelmina, who visited the exhibition, the Vereeniging Historisch Scheepvaart Museum, an association which aimed at founding a maritime museum of a nationwide scope, the museum was founded in 1921. In 1973 the expanded collection was tranferred to the monumental 17th-century Navy Arsenal, 's Lands Zeemagazijn, in the eastern docks, which was completely restored and refurbished in 1981. The collection comprises some materials of interest for the maritime relations between the Low Countries and the Ottoman Empire, among them three fermāns, A.4898(14-16), which had been acquired from the collection of Jacob Baart de la Faille (1795-1867), professor of Medicine in Groningen (1832-1865, cf. NNBW IV, cols. 597-598), and sold at public auction in 1868; they had formerly belonged to his grand-father, Ambroise Veijdt of the Antwerp firm of De Heijder Veijdt \& Co.

Literature: Sjoerd de Meer, 's Lands Zeemagazijn (Zutphen 1994), esp. pp. $71-86$.

\section{A.4898(14) \\ A passport}

An original copy of a fermān issued on request of the Austrian internuntius (orta elçisi) to the Porte, Baron de Herbert Rathkeal [Peter Philipp Herbert Freiherr von Rathkeal, 1733-1802, in function 1780-1789, cf. BLKO VI, pp. 352-357], to grant safe conduct to the ship de Stad Lier under Captain Dirick Lauerman [sailing for the Antwerp firm of De Heijder Veijdt \& Co.] in the Mediterranean Sea, dated at the beginning of Rebïü l-ähir 1197 (6-15 March 1783). The text is headed by a tugra in gold-dusted black ink of Sultan 'Abulhamīd I (see Umur, pp. 270-277). A brief description in French is found on the back (4 lines).

Glazed white paper; $760 \times 530 \mathrm{~mm} ; 14$ lines; dìvāni. 


\section{A.4898(15)}

A passport

An original copy of a fermān issued on requeste of the Austrian internuntius (orta elçisi) to the Porte, Baron de Herbert Rathkeal (cf. above), to grant safe conduct to the ship la Dame Catherine under Captain Hans Hoier [sailing for the Antwerp firm of De Heijder Veijdt \& Co.] in the Mediterranean Sea, dated at the end of Şevvāl 1196 (28 September-7 October 1782). The text is headed by a tugra in gold-dusted black ink of Sultan 'Abulhamīd I (see Umur, pp. 270-277). A brief description in French is found on the back (4 lines).

Glazed white paper; $760 \times 530 \mathrm{~mm} ; 13$ lines; dìvānī.

\section{A.4898(16)}

A passport

An original copy of an official document, addressing $k \bar{a} \dot{z} \bar{\imath}$ s and other authorities on the way between Izmir and Istanbul, on behalf of two Dutch gentlemen (Felemenk begzādeler), [Lieutenant B.G.] Escher and [aspirant de ${ }^{\text {ire }}$ classe, J.A.K] van Hasselt, instructing them to let the men pass along unhindered, and see to their comfort as regards lodging and horses; the document was handed over to the [Dutch] consul in Izmir. It is signed by 'Ömer Luṭ̂i, nāzir-i ihtisāb (d. 1252/1836-1837, cf. SO IV, p. 1322; see also Schmidt, Opium Trade, p. 49, passim) - the calligraphed signature is adorned with two tugs —and dated 29 Rebǐü l-evvel [12]46 (17 September 1830). A signature and a seal are found on the back. (The journey of the two officers is documented in consular correspondence: the consul in Izmir, Jacob van Lennep, informed the envoy in Istanbul, Caspard Testa, on the 17th that the men had arrived on the 16th-they were crew members of the Dutch Navy brig Kemphaan - and would travel to Istanbul over land in the company of the cavass 'Alī. Testa informed Van Lennep on the 28th that the men had savely arrived, and had been introduced to the kapudan paşa and the ser'asker. They had left the city on the previous day. See NA, file Nederlands Gezantschap in Turkije 1814-1872, 164 \& 165.)

Glazed white paper; $540 \times 300 \mathrm{~mm}$; irregular dìvānī; 9 lines. 